
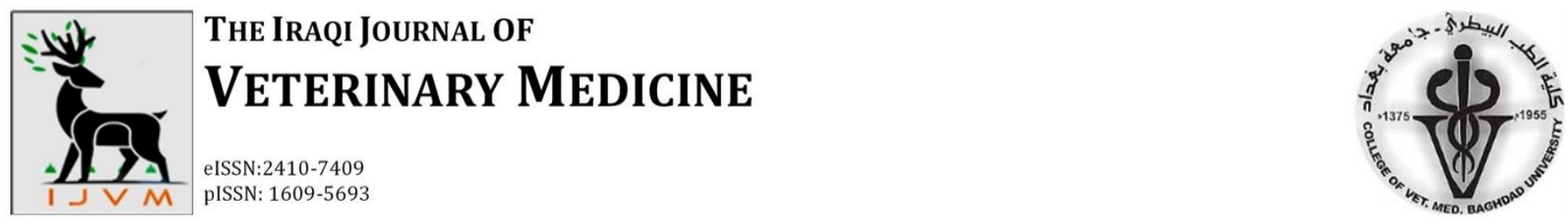

\title{
OPEN ACCESS \\ Clinical and Biochemical Profile of Iraqi Local Breed Cows During Pregnancy and Early Lactation
}

\author{
Al-Bayati 0 A Shareef ${ }^{*}$, and Oday K Luaibi \\ Department. of Internal and Preventive Veterinary Medicine, College of Veterinary Medicine, \\ University of Baghdad, Iraq
}

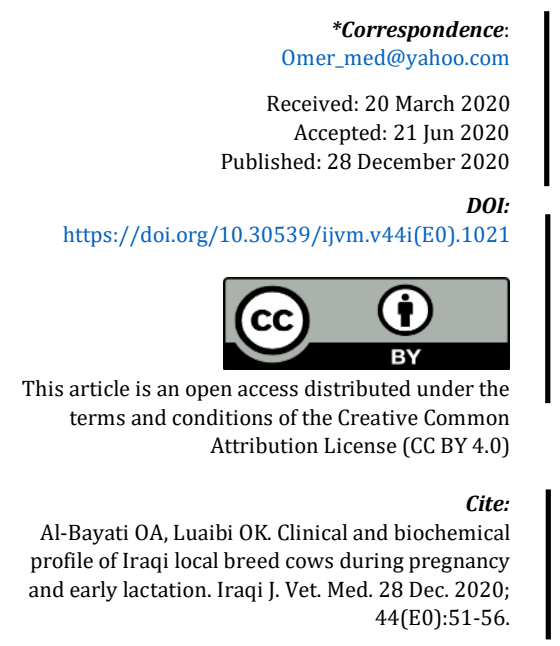

${ }^{*}$ Correspondence:

Received: 20 March 2020 Accepted: 21 Jun 2020

DOI:

https://doi.org/10.30539/ijvm.v44i(E0).1021

is article is an open access distributed under the Attribution License (CC BY 4.0)

Cite:

Al-Bayati OA, Luaibi OK. Clinical and biochemical profile of Iraqi local breed cows during pregnancy 44(E0):51-56

\begin{abstract}
$\begin{array}{lllllllllllllllll}\mathbf{A} & \mathbf{B} & \mathbf{S} & \mathbf{T} & \mathbf{R} & \mathbf{A} & \mathbf{C} & \mathbf{T}\end{array}$
This study was conducted in Al-Alam region, which is located in Salah Al-Din Governorate, on first month pregnant Iraqi local cows $(n-10)$. The follow up extended from the first month of pregnancy up to the end of the first month post-parturition during that some clinical and biochemical parameters were measured in the serum. Blood samples from the jugular vein of cows were collected monthly for the whole period of experiment and divided into four stages: early pregnancy, mid pregnancy, late pregnancy, and early lactation immediately after birth. It was observed that the temperature, respiration rate, and heart rate increased gradually and significantly $(\mathrm{P} \leq 0.05)$ with the progress of pregnancy reaching to its highest value in the last period of pregnancy and decreased after birth. The last trimester of pregnancy and the early lactation were also showed a significant decrease $(P \leq 0.05)$ of the phosphorus, calcium, iron, and copper concentrations compared to the first and second trimesters of the pregnancy however, significant increases in other biochemical values $(\mathrm{P} \leq 0.05)$ were observed in urea and creatinine concentrations in the last trimester of pregnancy and early lactation. In addition to a significant decrease $(\mathrm{P} \leq 0.05)$ of the ratios of concentrations of glucose, total protein, albumin, and globulin in the last period of pregnancy compared to other periods. The decrease in the value of globulin continued until the early birth period while the study did not show any significant difference in the concentration of bilirubin between durations. Finally, values of the ALT, AST and ALP enzymes showed significant increases $(P \leq 0.05)$ in their concentrations in the last period of pregnancy. It is concluded that possible changes in the biochemical parameters of the local Iraqi cows' blood during pregnancy and early lactation are existed
\end{abstract}

$\mathbf{K}_{\text {eywords: biochemical, Iraqi local cows, pregnant cows, lactation }}$

\section{INTRODUCTION}

$S_{\mathrm{c}}^{\mathrm{e}}$ erum biochemical profile measurement is a preclinical diagnostic tool for determining the animals nutritional status, and both of productive and reproductive disturbances (1). Biochemical analyses of blood are useful to get an understanding of the health and metabolic status of animals. Through the diagnostic procedure, it is especially useful to compare the values attained from ill animals with normal values in healthy animals (2). The mineral levels and another biochemical parameters of cows are depended on a large number of intrinsic and extrinsic factors such as species, breed, sex, age, nutritional with health status, nutrients supplementation, physiological and seasonal variations (3-6) and climate, origin, management practice, geographical distribution and stages of gestation 
$(7,8)$. Pregnancy and lactation are physiologic statuses which may influence metabolism in cows and induce stress (9). The periparturient period is important in terms of its influences on the health and subsequent performance of dairy cows since cows develop serious metabolic and physiological changes during these periods (10). It is well known that through the pregnancy, all the metabolic pathways are involved in sustaining of fetus growth (11). The period of transition in cows between late pregnancy and early lactation shows a huge metabolic challenge to the high yielding dairy cow and the biochemical profiles are important in evaluating the health status of cows during this transition $(11,12)$. Immediately after the parturition, high rates of body condition score losses due to a severe negative energy balance status, indicated by alterations in blood metabolic and hormone profiles that change physiologically in pregnancy (13).

Alterations in metabolic function of the transition period related to increase the requirements of energy that is needed by the fetus and lactogenesis, due to metabolic, behavioral, and hormonal changes that occur at the time of parturition; and cows had a marked decrease in dry matter intakes (14). From the beginning of pregnancy, cow should be provided with the necessary amounts of the nutrient, which would satisfy its own vital needs, and the needs of the fetus and lactation. Deficiency or excessive amount of energy, biologically active agents in diets lead to disorders in the metabolism of pregnant cows (15-17). Little information is available about how this need affects the physiological phase. During the last years, the average milk production is increased and conversely decreased due to the negative energy balance and the reproducibility (18). Finally (19) concluded that the gestation and lactation periods have a significant effect on the activity of biochemical indices in the blood of dairy cows; therefore, there is a need for constant periodic determination for the described indices. Health status of the present study is an attempt for providing a picture of dynamics of selected biochemical parameters in Iraqi local cows from the period of beginning pregnancy to one month after parturition for providing new and useful information about the guidelines of pregnant cows' management strategies during different physiological phases of pregnancy and early lactation.

\section{MAterials AND METHODS}

\section{Animals and Clinical Examination}

All procedures conducted in this study was reviewed and approved by the scientific committee in the College of Veterinary Medicine, University of Baghdad in accordance with the ethical standards of animal welfare.

A total of ten apparently healthy pregnant cows from $\mathrm{Al}$ Alam in Salah-Aldin governorate were included in the study of first-month gestation between January and December
2019. Three to eight years old was the age range. All the cows were living in the same environment. The animals were monitored for a period of ten months.

All cows were subjected to a clinical examination, which included temperature, respiration, and pulse rate, as well as ruminal movement, which was recorded at the end of each month according to the manner described by $(20,21)$. According to the method proposed by (22)., a periodic rectal examination was used to detect the amount of pregnancy and predict the parturition date of the cows under research.

\section{Sampling and Biochemical Tests}

The blood samples were collected from all cows monthly; then the months divided into four periods as Early pregnancy (1-3 months), Mid pregnancy (4-6 months), Late stage (7-9 months) and early lactation. Blood samples (8 $\mathrm{ml}$ ) were collected according to (23), from the jugular vein in test tube without anticoagulant to serum isolated for a purpose of biochemical values examination, after centrifuging at $3000 \mathrm{rpm}$ for $15 \mathrm{~min}$ for proper separation of serum from coagulated blood. Serum was separated and stored in aliquots at $-20^{\circ} \mathrm{C}$ to be examined.

Biochemical determination of serum concentrations of phosphorus $(\mathrm{P})$, calcium $(\mathrm{Ca})$, iron $(\mathrm{Fe})$, copper $(\mathrm{Cu})$, glucose, Urea, creatinine, bilirubin, total protein, albumin, globulin, alanine aminotransferase (ALT), aspartate aminotransferase (AST), and alkaline phosphatase (ALP) were carried out using commercial test kits supplied by (Assel S.r.l., Italy) using the atomic absorption spectrophotometer according to the method described by $(24,25)$ and UV spectrophotometer $(26)$.

\section{Statistical Analysis}

Data were Statistically analyzed using the packaged SPSS program for windows version 10.01. Data were presented as mean \pm Standard Error (SE). Differences between groups were determined by one-way analysis of variance (ANOVA). The significance level was set at $(\mathrm{P} \leq$ 0.05) (27).

\section{RESULTS AND DISCUSSION}

Results of clinical signs through pregnancy periods and early lactation are presented in Table 1 . The clinical examination showed a variation in parameters between the months of pregnancy as the average body temperature was $38.4 \pm 0.11^{\circ} \mathrm{C}$ at the early of pregnancy and $38.4 \pm 0.13^{\circ} \mathrm{C}$ at the mid-pregnancy, $38.7 \pm 0.09{ }^{\circ} \mathrm{C}$ in the late pregnancy and $38.4 \pm 0.12{ }^{\circ} \mathrm{C}$ after birth in the first month. Significant differences among the average temperature during pregnancy and the average rate after birth at the $(\mathrm{P}<0.05)$ as the temperature gradually increased with the progress of the pregnancy and reached the highest level in the late 
pregnancy then started to decrease after Birth. The increase of temperature during the period of pregnancy may be caused by an increase in the speed of metabolic processes in the dams' body for the fetus feeding status. Hormones caused an increase in temperature during pregnancy and the high level of the progesterone hormone during pregnancy caused an increase in temperature, and the low level of progesterone and the high level of estrogen that occurred after birth led to a decrease in temperature (28). The respiratory rate was $22.4 \pm 1.14,24.2 \pm 1.01,26.7 \pm 1.13$ and $23.7 \pm 0.52 \mathrm{~min}$, at the early, mid pregnancy, late pregnancy, and early lactation, respectively. The study found that there were changes in respiratory rates during pregnancy and after birth. The respiratory rate increased gradually during pregnancy, peaked significantly $(\mathrm{P}<0.05)$ in late pregnancy before birth, and then began to decline after birth. The rate of breathing increased during pregnancy due to the increase of tidal volume (the volume of normal breathing). The reason for the increase may be due to fetal growth, as a natural result of increased body temperature, the rate of respiration and pulse increases (20). The heart rate was $64.3 \pm 1.23,65.9 \pm 1.19,69.7 \pm 1.45$ and $65.5 \pm 1.18$ beats min at the early, mid and late pregnancy, and early lactation, respectively. It was noted that significant differences between the heart rate during pregnancy and its rate after birth at the level of $(\mathrm{P}<0.05)$ was gradually increased with the progress of pregnancy reached to the highest level in the late pregnancy period then began to decrease after birth in early lactation period. These changes allowed the heart and blood vessels to come with the increased metabolic needs during pregnancy. The effectiveness of the thyroid gland increased during pregnancy, and the effectiveness of thyroid hormone (thyroxin) affected all organs, especially the heart, which responded to the least change in the level of thyroxin. The increased thyroid effectiveness during pregnancy had a direct effect on the heart, causing an increase in the rate of heartbeat leading to increase blood volume, and stroke volume (29).

The study showed significant $(\mathrm{P}<0.05)$ decreased in ruminal movement in period of late pregnancy which was $2.1 \pm 0.14 \mathrm{~min}$, and the decrease in ruminal movements or ruminal atony near parturition could be attributed to increase of intraabdominal pressure by gravid uterus on rumen through advanced pregnancy period and somewhat reduced calcium level during early post parturient stage (30).

Results in Table 2 revealed that minerals level showed that there were significant decreases $(\mathrm{P}<0.05)$ in phosphorus concentration in late pregnancy $(5.76 \pm 0.09$ $\mathrm{mg} / \mathrm{dl})$, and early lactation $(5.74 \pm 0.21 \mathrm{mg} / \mathrm{dl})$ when compared with early and mid-pregnancy.

Table 1. Clinical signs through pregnancy periods and early lactation ${ }^{1}$

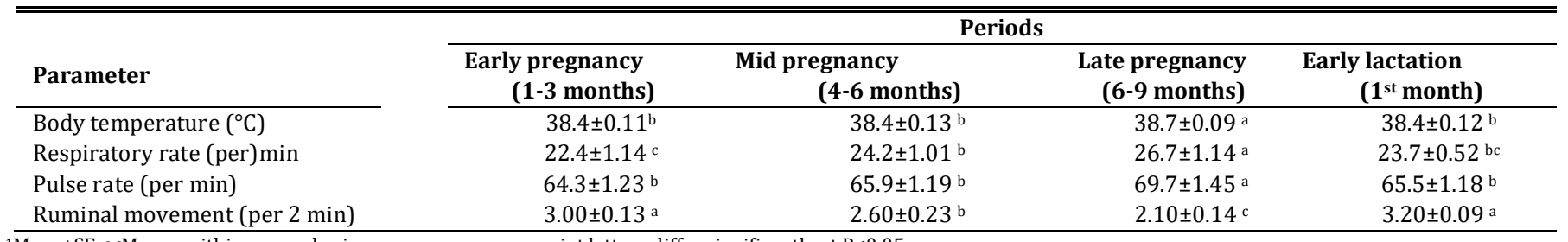

1 Mean \pm SE. a-cMeans with in a row sharing uncommon superscript letters differ significantly at $\mathrm{P} \leq 0.05$

The study also noticed the same significant difference in calcium parameters in late pregnancy $8.52 \pm 0.09 \mathrm{mg} / \mathrm{dl}$ and $7.55 \pm 0.29$ in early lactation. Because of the increased transmission of phosphorous and calcium from the cows' blood to the fetus, the fetus needs phosphorous and calcium in large quantities to build the bone in late period of pregnancy (31). Phosphorus and Calcium requirements of cows varied depending on the stage of pregnancy, growth, and lactation $(32,33)$. The iron also decreased significantly $(\mathrm{P}<0.05)$ in late pregnancy which was $96.3 \pm 3.55 \mu \mathrm{g} / \mathrm{dl}$ and early lactation which was $90.3 \pm 3.36 \mu \mathrm{g} / \mathrm{dl}$ when compared to early and mid-pregnancy which was $103 \pm 4.23 \mu \mathrm{g} / \mathrm{dl}$ and $104 \pm 3.89 \mu \mathrm{g} / \mathrm{dl}$ respectively. According to (34), it was suggested that the pregnant cows were more susceptible to iron deficiency due to fetus growth requirement, while (35) recorded iron loss in colostrum to be 10-17 times more than in ordinary milk. Therefore, the iron level of blood serum decreased in cows at the end of pregnancy and after birth. As for copper, it was gradually decreased significantly $(\mathrm{P}<0.05)$ in mid-pregnancy, late pregnancy and early lactation which was $107 \pm 2.03,101 \pm 2.34$ and $94.1 \pm 1.74$ $\mu \mathrm{g} / \mathrm{dl}$, respectively when compared with to early pregnant $112 \pm 2.16 \mu \mathrm{g} / \mathrm{dl}$. This was due to increase demand and utilization of maternal copper for fetal nervous systems development (36).

The Study results in Table 3 of other biochemical parameters showed significant decreases $(\mathrm{P}<0.05)$ of glucose level in late period of pregnancy which was $62.7 \pm$ 2.54. This may be caused by an increase of fetus need for glucose due to increased fetal development during the last period of pregnancy (37).

A significant increased $(\mathrm{P}<0.05)$ of the levels of urea and creatinine in late pregnancy and early lactation in which urea was $26.3 \pm 1.21 \mathrm{mg} / \mathrm{dl}$ and $33.3 \pm 0.97 \mathrm{mg} / \mathrm{dl}$, while 
creatinine was $1.50 \pm 0.07 \mathrm{mg} / \mathrm{dl}$ and $1.73 \pm 0.13 \mathrm{mg} / \mathrm{dl}$, respectively. When compared to early and mid pregnancy periods, the urea was $20.9 \pm 1.06$ and $21.83 \pm 1.45$, creatinine was $1.23 \pm 0.04$, and $1.38 \pm 0.06$, respectively and this may agree with the indicated of (38) in which the renal function, principally represented by urea and creatinine concentrations was significantly affected during the different physiological phases, as suggested by other studies and the increase in urea blood serum levels during the lactation period despite the late gestation was strictly dependent on the dietary intake of protein. More relevant during lactation because of the requirements were increased, the increase in serum creatinine levels could be recognized as the development of the fetal musculature.

Table 2. Serum parameters through pregnancy periods and early lactation ${ }^{1}$

\begin{tabular}{|c|c|c|c|c|}
\hline \multirow[b]{2}{*}{ Parameter } & \multicolumn{4}{|c|}{ Periods } \\
\hline & $\begin{array}{l}\text { Early pregnancy } \\
\text { (1-3 months) }\end{array}$ & $\begin{array}{l}\text { Mid pregnancy } \\
\text { (4-6 months) }\end{array}$ & $\begin{array}{l}\text { Late pregnancy } \\
\text { (7-9 months) }\end{array}$ & $\begin{array}{l}\text { Early lactation } \\
\left(1^{\text {st }} \text { month }\right) \\
\end{array}$ \\
\hline $\mathrm{P}(\mathrm{mg} / \mathrm{dl})$ & $6.17 \pm 0.12$ a & $6.14 \pm 0.10$ a & $5.76 \pm 0.09 \mathrm{~b}$ & $5.74 \pm 0.21 \mathrm{~b}$ \\
\hline Ca (mg/dl) & $9.55 \pm 0.23$ a & $9.32 \pm 0.15^{\text {a }}$ & $8.52 \pm 0.07 \mathrm{~b}$ & $7.55 \pm 0.29^{c}$ \\
\hline $\mathrm{Fe}(\mu \mathrm{g} / \mathrm{dl})$ & $103 \pm 4.23$ a & $104 \pm 3.89$ a & $96.3 \pm 3.55^{b}$ & $90.0 \pm 3.36^{c}$ \\
\hline $\mathrm{Cu}(\mu \mathrm{g} / \mathrm{dl})$ & $112 \pm 2.16 \mathrm{a}$ & $107 \pm 2.03 \mathrm{~b}$ & $101 \pm 2.34 \mathrm{c}$ & $94.1 \pm 1.74 \mathrm{~d}$ \\
\hline
\end{tabular}

${ }_{1}^{1}$ Mean \pm SE. a-d Means within a row sharing uncommon superscript letters differ significantly at $\mathrm{P} \leq 0.05$

During the late gestation, the dam, for the fetal maternal circulation, assumed the load of organic waste of the newborn (39), and the same causes indicated by (40) who reported the possibilities of elevation of creatinine level near calving. As for the concentration of bilirubin, the current study did not record any significancy between the periods of physiological stages in studies of cow. While the total protein concentration proved to be gradually decreased and with the progression of pregnancy until reaching decreased significant $(\mathrm{P}<0.05)$ in late pregnancy and early lactation levels $6.3 \pm 0.32 \mathrm{~g} / \mathrm{dl}$ and $6.59 \pm 0.24 \mathrm{~g} / \mathrm{dl}$, ,respectively. The variations reflected the maternal requirements of proteins need for milking and providing immunoglobulins $(38,41)$. Serum total proteins as parturition approached decreased. The latter occurrence might be due to the fetus synthesized all its proteins from the amino acids that derived from the dam and fetal muscle growth reaching its maximum size at late pregnancy (42). Albumin was decreased significantly $(\mathrm{P}<0.05)$ in late pregnancy which was $2.81 \pm 0.21 \mathrm{~g} / \mathrm{dl}$ while was $3.55 \pm 0.13$ $\mathrm{g} / \mathrm{dl}, 3.36 \pm 0.43 \mathrm{~g} / \mathrm{dl}, 3.46 \pm 0.04 \mathrm{~g} / \mathrm{dl}$ in early pregnancy, mid pregnancy, and early lactation respectively. The decrease in the content of albumin in the blood serum of pregnant cow related to the effect of toxins on the liver and weakening of its protein-synthesizing function. The liver synthesized $80 \%$ of all albumins. A Significant decrease in the level of albumin indicated a deficiency of amino acid and proteins in the organism of pregnant cows (43). Globulin only decreased in late pregnancy and early lactation which was $3.13 \pm 0.22 \mathrm{~g} / \mathrm{dl}$, Serum globulins showed a significant decrease after parturition period, which associated mainly with the production of colostrum that is rich in antibodies which derived from $\gamma$-globulins and other immunological changes occurred during parturition (44).
The activity of ALT, AST and ALP that tested in current study showed the increases significantly $(\mathrm{P}<0.05)$ in Late pregnancy which was $31.9 \pm 1.34 \mathrm{IU} / \mathrm{L}, 104 \pm 2.14 \mathrm{IU} / \mathrm{L}$ and 93.1 $\pm 2.25 \mathrm{IU} / \mathrm{L}$ in ALT, AST, and ALP, respectively when compared to other periods. The excessive activity of ALP detected in pregnant cows of study could occur due to presence of corpus luteum that responsible on the production of progesterone required establishment and pregnancy maintenance (45). Furthermore, the high metabolic rate or increasing bone metabolism due to the absence of mineral feed additives in feeds of dairy cows might be a result in an elevation of ALP activity (46). The amine transporter enzymes increased in pregnancy due to increase liver weight and reached the highest levels when there was a lack of protein concentration and fat depletion to manufacture energy (47). The highest levels of this enzyme during pregnancy may reflect an existence of ketosis, lower dry matter intake or fatty liver syndrome (48). The cause of the increase in the last pregnancy was the secretion of the placenta of this enzyme (49), in addition to increase the level of these enzymes which was affected by nutrition deficiency caused and negative energy balance due to increase of energy requirement in late pregnancy period (50), It reached its highest concentration during the last period of pregnancy. The study of the activity of alanine aminotransferase (ALT) and aspartate aminotransferase (AST) was significantly increased for defining the general physiological condition of an animal organism. The pregnant cows with progressive endogenous intoxication were observed to have a significant increase in the activity of the above mentioned aminotransferases in their blood over the last months of pregnancy. 
Table 3. Biochemical examination parameters through pregnancy stages and early lactation ${ }^{1}$

\begin{tabular}{|c|c|c|c|c|}
\hline \multirow[b]{2}{*}{ Parameter } & \multicolumn{4}{|c|}{ Periods } \\
\hline & $\begin{array}{l}\text { Early pregnancy } \\
\text { (up to3 months) }\end{array}$ & $\begin{array}{l}\text { Mid pregnancy } \\
\text { (up to } 6 \text { months) }\end{array}$ & $\begin{array}{l}\text { Late pregnancy } \\
\text { (up to } 9 \text { months) }\end{array}$ & $\begin{array}{l}\text { Early lactation } \\
\text { (1 } \text { st }^{\text {st }} \text { month) }\end{array}$ \\
\hline Glucose (mg/dl) & $65.6 \pm 2.55^{a}$ & $66.1 \pm 2.13^{a}$ & $62.7 \pm 2.54^{b}$ & $65.9 \pm 1.67 \mathrm{a}$ \\
\hline Urea (mg/dl) & $20.9 \pm 1.06^{c}$ & $21.8 \pm 1.45^{c}$ & $26.3 \pm 1.21^{b}$ & $33.3 \pm 0.97$ a \\
\hline Creatinine (mg/dl) & $1.23 \pm 0.04 \mathrm{~b}$ & $1.38 \pm 0.06^{b}$ & $1.50 \pm 0.07 \mathrm{a}$ & $1.73 \pm 0.13 \mathrm{a}$ \\
\hline Total bilirubin (mg/dl) & $0.31 \pm 0.03^{a}$ & $0.36 \pm 0.04$ & $0.38 \pm 0.02^{a}$ & $0.41 \pm 0.05^{a}$ \\
\hline Total protein (g/dl) & $7.34 \pm 0.12^{a}$ & $7.18 \pm 0.15^{a}$ & $6.30 \pm 0.32^{c}$ & $6.59 \pm 0.24 \mathrm{~b}$ \\
\hline Albumin (g/dl) & $3.55 \pm 0.13^{a}$ & $3.36 \pm 0.43^{a}$ & $2.81 \pm 0.21 b$ & $3.46 \pm 0.04 \mathrm{a}$ \\
\hline Globulin (g/dl) & $3.79 \pm 0.15^{a}$ & $3.81 \pm 0.16^{a}$ & $3.48 \pm 0.24 b$ & $3.13 \pm 0.22 b$ \\
\hline ALT (IU/L) & $24.4 \pm 1.45^{b}$ & $26.5 \pm 1.32 \mathrm{~b}$ & $31.9 \pm 1.34^{\mathrm{a}}$ & $25.4 \pm 3.71 \mathrm{~b}$ \\
\hline AST (IU/L) & $96.8 \pm 2.23^{c}$ & $99.0 \pm 1.87$ b & $104 \pm 2.14^{a}$ & $100 \pm 3.80 b$ \\
\hline ALP (IU/L) & $89.9 \pm 2.34 b$ & $89.6 \pm 203 b$ & $93.1 \pm 2.25^{\mathrm{a}}$ & $87.5 \pm 3.86^{c}$ \\
\hline
\end{tabular}

${ }_{1}^{1}$ Mean \pm SE. a-c Means within a row sharing uncommon superscript letters differ significantly at $\mathrm{P} \leq 0.05$

In conclusion, we found significant changes in clinical, mineral, and some other biochemical changes in healthy pregnant local cows. Our results propose the minerals and other biochemical changes profiles need to be evaluated regularly in different periods of pregnancy and lactation to diagnose deficiencies and imbalances to achieve set targets in terms of production performance by adjusting feeding and mineral supplementation.

\section{ACKNOWLEDGEMENTS}

$$
\mathrm{N} / \mathrm{A}
$$

\section{FUNDING}

These authors declare that above-submitted work was not funded by any governmental or private funding source nor supported by any financial projects.

\section{CONFLICT OF INTEREST}

The authors declare that there is no conflict of interest.

\section{REFERENCES}

1. Pathan MM. Comparative studies on haemato-biochemical profile of cyclic and non-cyclic holstem-friesian cross breed cows. Wayamba J. Anim. Sci.2011; 13: 131-140.

2. Jezek J, Klopcic M, Klinkon M. Influence of age on biochemical parameters in calves. Bull. Vet. Inst. palawy. 2006; 50: 211-214.

3. Al-Shami SA. Comparative study of haematological and blood biochemical components in milk-fed and conventionally reared hassawi breed calves. Sci. J. King Faisal Univ. Basic Applied 2007; 8:99-106.

4. Mohammed AK, Mohammed G. Akerejola 00. Haematological and serum biochemical changes in Bunaji work bulls after farmland ridging exercise in Kaduna State, Nigeria. J. Anim. Vet. Ad.2007; 6: 576-579.

5. Gattani A, Sareen M. Influence of age and season on thyroid activity and blood biochemical profile in magra rams under a rid tropical environment. Indian J. Small Rumin. 2011; 17: 237-239.
6. Usha S, Mohanty TK, Senthilkumar P. Effects of physiological status and season on Blood biochemical and mineral Profile of Holstein Friesian cross bred cattle. Int. J. Curr. Microbiol. Appl. Sci. 2018; 7(12): 1122-1132.

7. Mahima KV, Singh AK, Verma V, Kumar S, Singh K, Roy D. "Hematological and serum biochemical profile of apparently healthy hariana cattle heifers in Northern India," Pak. J. of Bio. Sci. 2013; 16(21): 1423-1425.

8. Cozzi G. "Short communication: Reference values for blood parameters in Holstein dairy cows: Effects of parity, stage of lactation, and season of production. J. Dairy Sci. 2011; 94: 38953901.

9. Iriadam M. Variation in certain hematological and biochemical parameters during the peri-partum period in Kilis does. Small Rum. Res.2007; 73: 54-57.

10. Tanaka M, Kamiya Y, Suzuki T, Nakai Y. Changes in oxidative status in periparturient dairy cows in hot conditions. Anim. Sci. J. 2011; 82: $320-324$.

11. Bell A, Burhans WS, Overton TR. Protein nutrition in late pregnancy, maternal protein reserves and lactation performance in dairy cows. Proceedings of the Nutrition Society.2000; 59: 119126.

12. Hawagane SD, Shinde SB and Rajguru DN. Haematological and blood biochemical profile in lactating buffaloes in and around Parbhani city. Vet. World. 2009; 2: 467-469.

13. Wathes D, Cheng Z, Chowdhury W, Fenwick MA, Fitzpatrick R, Morris DG and Patton J. Murphy Negative energy balance alters global gene expression and immune responses in the uterus of postpartum dairy cows. Physio Genomics. 2009; 39: 1-13.

14. Elshahawy II, Abdullaziz IA. Haemato-Biochemical Profiling in Relation to Metabolic Disorders in Transition Dairy Cows. Alexandria J. of Vet. Sci. 2017; 55 (2): 25-33.

15. Macmillan K, López Helguera I, Behrouzi A, Gobikrushanth M, Hoff B, Colazo MG. Accuracy of a cow-side test for the diagnosis of hyperketonemia and hypoglycemia in lactating dairy cows. Res. in Vet. Sci. 2017; 115, 327-331.

16. Slivinska L, Demydjuk S, Shcherbatyy A, Fedorovich V, Tyndyk I. Etiology and clinical biochemical parameters of blood for nutritional osteodystrophyof cows. Journal of Dairy Sci. 2017; 73: 79-83.

17. Vieira-Neto A, Lima IRP, Lopes F, Lopera C, Zimpel R, Sinedino LDP. Use of calcitriol to maintain postpartum blood calcium and improve immune function in dairy cows. Journal of Dairy Science. 2017; 100(7): 5805- 5823.

18. De Garis PJ, Lean IJ, Rabiee AR, Stevenson, MA. Effects of increasing days of exposure to prepartum diets concentration of certain blood metabolites in dairy cows. Australian Veterinary Journal. 2010; 88: 137-145. 
19. Kadhim MS, Ali BH. Levels of some biochemical markers in sera of pregnant and non-pregnant lactating dairy cows in Baghdad, Iraq. Iraqi J. Vet. Sci. 2019; 33(2): 353-358.

20. Kelly WR. "Veterinary Clinical Diagnosis". $3^{\text {rd }}$ ed., William Clows Ltd., London1984; 3: 230-266.

21. Constable PD, Hinchcliff KW, Done SH, Grunberg, W. Veterinary Medicine: A Textbook of the Diseases of Cattle. Horses, Sheep, Pigs and Goats, $11^{\text {th }}$ ed., USA: Saunders; 2017. pp 1630-1738.

22. David EN, Timothy GB, Gary CE. Arthur's Veterinary Reproduction and Obstetrics. 8th ed. London: W.B. Saunders, U.K;2001. p 112135.

23. Pugh DG. A textbook of Sheep and Goat Medicine. 1st ed. USA: W.B. Saunders; 2002. pp 7216-9052.

24. Daly JA, Ertingshausen G. "Direct method for determining inorganic phosphate in serum with the" Centrifi Chem". J of Cl. Chem. 1972; 18 (3): 263-265.

25. Tietz NW, editor. Textbook of Clinical Chemistry, $3^{\text {rd }}$ ed. Philadelphia: Ashwood W. B. Saunders; 1998. pp 1395-1406.

26. Murray RL. Alanine aminotransferase In: Kapan LA, Pesce AJ, Editors. Clinical chemistry. Theory, analysis. CV Mosby St Louis;1984; pp 1090-1250.

27. SPSS. Sample Power statistics, SPSS 11.5, Syntax reference guide for SPSS Base. SPSS Inc., 233 South Wacker Drive, Chicago. 2000.

28. Radostits OM, Gay CD, Hinchcliff K, Constable PD, editors. A Textbook of Disease of Cattle, Sheep , Pigs , Goat \& Horses ,10th ed. London: Saunders ; 2006 .p1777 - 2048.

29. Fadel, BM. Hyperthyroid heart disease Clinical cardiology. 2000; 23(6): 402-408.

30. Goff JP. Transition period management and nutrition problems-A few solutions. In: Proceedings of the High Plains Dairy Conference, Albuquerque, NZ Vet J. 2008; 123-138.

31. Braithwaite GD. Calcium and Phosphorus requirements of the ewe during pregnancy and lactation. Br. J. Nutr.1983; 50: 711-722.

32. Betteridge K A survey of the phosphorus content of pastures and the serum inorganic phosphorus content of dairy cows. NZ Vet J.1986; 34: 22-26.

33. Brzezinska M, Krawczyk M. Changes of the mineral profile of serum of goats in various physiological states. J. of Elem.2009;14: 649656.

34. Tapiero H, GateL, Tew KD. Iron deficiencies and requirements. Biomed. Pharmacotherapy. 2001; 55:324-32.

35. Goran GV, Crivineanu V, Rotaru E, Tudoreanu L, Hanganu A. Dyanmics of some mineral elements in sheep colostrum. omania; Bul. UASVM, Vet. Med. 2010; 67(2):81-87.

36. Elnageeb MA, Abdelatif AM. The mineral profile in desert ewes (Ovisaries): Effects of pregnancy, lactation and dietary supplementation. American - Euras. J. Agric. Environ. Sci.2010; 7: 18-30.
37. Hamadeh ME, Bosted H, Failing K. Studies on relevant metabolism parameters In blood plasma of highly pregnant and non-pregnant ewes. Berl. and Munc. Tier. Woch. 1996; 109: 81-86.

38. Roubies N, Panouis N, Fytianou A, KatsoulosPD, Giadinis N, Karatzias $\mathrm{H}$. Effects of age and reproductive stage on certain serum biochemical parameters of Chios sheep under Greek rearing conditions. J. Vet. Med. 2006;53: 277-281.

39. Ferrell CL. Maternal and fetal influences on uterine and conceptus development in the cow: II. Blood Flow and nutrient flux. J. of Anim. Sci. 1991; 69: 1954-1965.

40. Ghanem MM, Mahmoud MEA, Abd El-Raof YMA, El-Attar HM. Metabolic profiles test for monitoring the clinical, haematological and biochemical alterations in cattle during periparturient period. Benha Vet. Med. J. 2012; 23(2): 13-23.

41. Mohri M, Sharifi K, Eidi S. Hematology and serum biochemistry of Holstein dairy calves: age related changes and comparison with blood composition in adults. Res. in Vet. Sci. 2007; 83: 30-39.

42. Jainudee MR, Hafez, ES. Gestation prenatal physiology and parturition. In: Hafez ESE (Ed): Reproduction in Farm Animals. Philadelphia :Lea and Febiger; 1994.p247-283

43. Gutyj B, Grymak Y, Drach M, Bilyk O, Matsjuk O, Magrelo N. The impact of endogenous intoxication on biochemical indicators of blood of pregnant cows. Reg. Mech. in Bio.2017; 8(3): 438-443.

44. Janku L, Pavlata L, Mišurová L, Filípek J, Pechová A, Dvořák R. Levels of protein fractions in blood serum of peri-parturient goats. Acta Vet. Brno.2011; 80: 185-190.

45. Tsiligianni T, Karagiannidis A, Saratsis P, Brikas P. Enzyme activityin bovine cervical mucus during spontaneous and induced estrus. Canadian J. Vet. Res. 2003; 67(3):189-193.

46. Šoch M, Písek L, Kroupová P, Šilhavá M, Št’astná J. Activity of alkaline phosphatase in cattle blood plasma according to stage of pregnancy. Slovak J Anim Sci. 2008; 41(1):39-41.

47. Vihan VS, Rai P. Certain haematological and biochemical attributes during pregnancy, parturition and post parturition periods In sheep and goats. Ind. J. Anim. Sci. 1987; 57:1200-1204.

48. García A, Cardoso FC, Thedy DX, González FH. Metabolic evaluation of dairy cows submitted to three different strategies to decrease the effects of negative energy balance in early postpartum. Pes. Vet. Br. 2011; 31(1):11-17.

49. Khan A, Bashir M, Ahmad KM, Javed MT, Yayyab KM, Ahmad M. Forecasting neonatal lamb mortality on the basis of haematological and enzymological profiles of thalli ewes at the pre-lambing stage. Small Ruminant Res.2002; 43: 149-156.

50. Ouanes I, Abdennour C, Aouaidjia N. Effect of cold winter on blood biochemistry of domestic sheep fed natural pasture. Annals of Biological Research. 2011; 2(2): 306-313.

\section{دراسة سريرية وكيموحيوية في الأبقار المحلية العراقية خلال فترة الحمل والرضاعة المبكرة}

$$
\begin{aligned}
& \text { عمر الثاني شريف سعيد 1وعدي كريم لعيبي2 } \\
& \text { 'فرع الطب الباطني و الوقائي ، كلبة الطب البيطري، جامعة تكريت، صلاح الدين، ففرع الطب الباطني و الوقائي ، كلية الطب البيطري، جامعة بغداد، }
\end{aligned}
$$

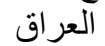

$$
\begin{aligned}
& \text { الخلاصة }
\end{aligned}
$$

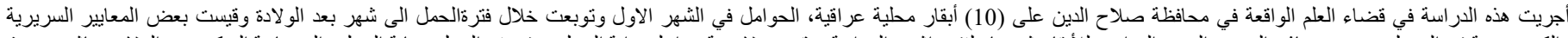

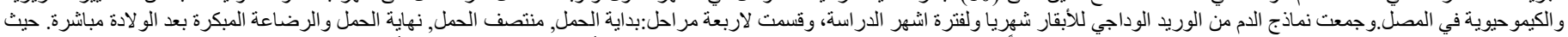

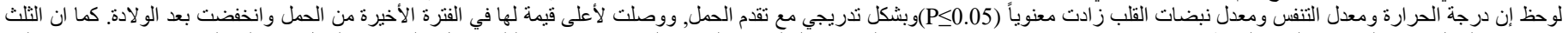

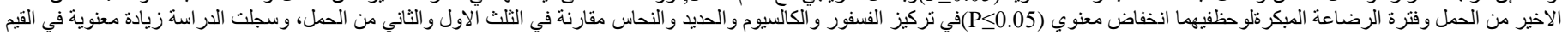

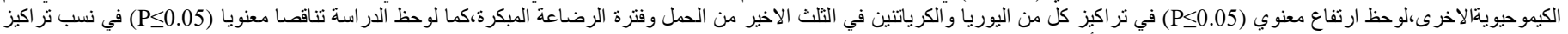

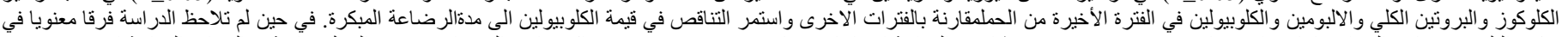

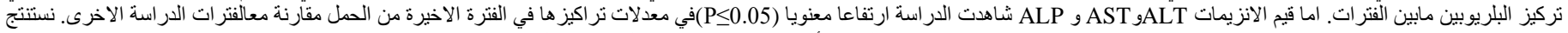

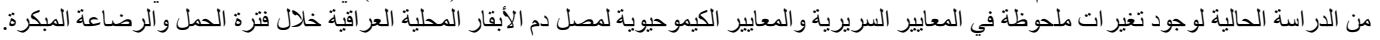

